\title{
Christ Apostolic Church women in dialogue with 1 Corinthians 14:34-36
}

\author{
Authors: \\ George O. Folarin ${ }^{1}$ \\ Stephen O. Afolabi² \\ Affiliations: \\ ${ }^{1}$ Department of Religious \\ Studies, Obafemi Awolowo \\ University, Ile-Ife, Nigeria \\ ${ }^{2}$ Christ Apostolic Church \\ Theological Seminary, \\ Ile-Ife, Nigeria

\section{Correspondence to:} \\ George Folarin \\ Email: \\ georgefolarin@yahoo.com

\section{Postal address:} \\ Department of Religious \\ Studies, Obafemi Awolowo \\ University, Ile-Ife, 220282 \\ Osun State, Nigeria \\ Dates: \\ Received: 13 Apr. 2012 \\ Accepted: 10 Sept. 2012 \\ Published: 29 Oct. 2012 \\ How to cite this article: \\ Folarin, G.O. \& Afolabi, \\ S.O., 2012, 'Christ Apostolic \\ Church Women in dialogue \\ with 1 Corinthians 14:34-36', \\ Verbum et Ecclesia 33(1), \\ Art. \#731, 7 pages. \\ http://dx.doi.org/10.4102/ \\ ve.v33i1.731
}

C 2012. The Authors. Licensee: AOSIS OpenJournals. This work is licensed under the Creative Commons Attribution License.
The command for women to be silent in church worship in 1 Corinthians 14 has generated much debate. After examining the controversies, this article has adopted the view that the sanction in verses 34-35 was a punishment for certain local offences of the female Christians in Corinth. The contention of the article is that interpretations of the text which criticise women 'talking to the congregation' when under inspiration in worship services, and which universalise such local rules are unfair. The article attempts to correct the sexist interpretation of 1 Corinthians 14:34-36 by re-interpreting the text in the context of women founding new assemblies, preaching, teaching, and leading congregational prayers in the Christ Apostolic Church (CAC), a Nigerian initiated Pentecostal denomination.

\section{Introduction}

Whilst the issue of women 'contributing authoritatively' within church worship is controversial, that of 'speaking authoritatively' within the same setting is more divisive, the issue of women ordination to church service is the most contentious. 1 Corinthians 14:34-36 however does not address the issue of church ordination. The first two issues are relevant to the discussion of the text selected for this study and would be appropriately considered later. Keener (2005:171) holds that 1 Corinthians 14:34-35 is fraught with problems and is difficult to interpret but Nelson (2005:27) weakly disagrees with him. A succinct and critical interpretation of the text would therefore be attempted.

The role women play in Yoruba traditional religions' worship depends on the cult. In cults like Oro and Agemo women are excluded from priesthood (Adewale 1998:7). Cults like Osun and Oya have only priestesses (Ademilokun 1998:57; cf. Adewale 1998:10-11). Other cults like OrisaNla and Yemoja on the other hand have both men and women in their priesthood (Ademilokun 1998:57-58). Like in the third model of traditional religious priesthood, women participate in Christ Apostolic Church (CAC) priesthood, and 1 Corinthians 14:34-35 would be interpreted from this perspective using the Pentecostal theological model in the context of the CAC.

\section{Women's silence (1 Cor 14:34-36): Models of interpretation}

The issue of women remaining silent in 1 Corinthians 14 is discussed generally in the context of church public worship (1 Cor 11-14). Firstly the veiling of women in worship (1 Cor 11:2-16) is discussed, then the sacrament of the Lord's Supper (1 Cor 11:17-34). The public use of spiritual gifts in church worship arguably covers the section (1 Cor 12:1-14:40; cf. Morris 1979:102-203; Maier 2004).

It is possible to isolate 1 Corinthians 14:26-40 as a smaller unit within the wider context. It focuses on prophetic utterances and this shows 1 Corinthians 14:34-36 to appear by implication, in the context of the use of prophecy. One should avoid to read the text uncritically. That would be to deny the textual and theological problems within these verses. Within 1 Corinthians 14:2640 , there are textual problems of varying degrees with verses $34-35$ and verses $37-39$. Only the textual problem in 1 Corinthians 14:34-35 is looked at here. Certain theological problems arise however from 1 Corinthians 14:34-35 on women roles in worship.

\section{The problem with the text of 1 Corinthians 14:26-40}

The textual problem with 1 Corinthians 14:26-40 centres on verses 34-35. The New Revised Standard Version (NRSV) translates the verses:

Women should be silent in the churches. For they are not permitted to speak, but should be subordinate, as the law also says, but if there is anything they desire to know, let them ask their husbands at home. For it is shameful for a woman to speak in church. (vv. 34-35) 
Nestle \& Aland render the verses:

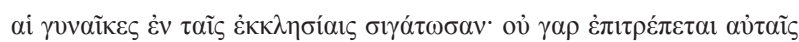

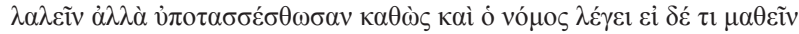

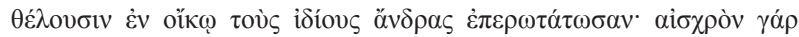

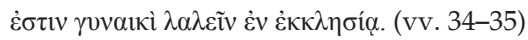

The authenticity of verses 34-35 has been rejected by scholars like Conzelmann (1975:246), and Preato (n.d.). The rejection is based on the following reasons: although most manuscripts place the verses after verse 33 , a few other manuscripts place them after verse 40 , and a common sign of gloss is a moveable text (Jn 7:53-8:11 is the locus classicus). Again, the theology of the verses is allegedly at variance with the teaching of Paul in other parts of the Letter (Fee 1987:699). Next, it is argued that verse 36 logically follows verse 33 which may suggest that verses 34-35 are either Paul's digression (Keener 1993a:483, 1993b:590) or an interpolation from someone else (Payne 2010; Murphy-O'Connor 1990:811-812). Moreover there is a sudden shift in Paul's correction of local problems in Corinthian worship in the preceding verses, to a universal rule, which would seem to be a non sequitur. The use of the plural and the definite article in the phrase 'in the assemblies (churches)' indicates that this rule was intended for all Christian churches (Derstine n.d.). Payne (1995:41, 240-262) even rejects verses $34-40$ and regards it as gloss. But many other scholars accept that all the verses are genuine. In the present article, I retain 1 Corinthians 14:34-35 after verse 33 because no single manuscript has been found that lacks the verses although available manuscripts vary in the precise placement of the verses (cf. Wallace 1998).

\section{Interpretations of the text}

At least three interpretive options are available on this text: that verses 34-35 were added by a non-Pauline writer, are not worthy of interpretation and, so should be excised (Barrett 1968: 332-333; Derstine n.d.); that the verses are declarative with Paul using them to forbid women from speaking in churches; and that the verses constitute Corinthian Christians' slogan or rabbinic sayings simply repeated by Paul. Only the first two options are briefly considered below.

Those who adopt any of the last two options have to contend with the link of verse $33 a$ with verse $33 b$ to mean 'for God is not a God of disorder but of peace, as in all the congregations of the saints,' or verse 33b with verse $34 \mathrm{a}$ as in Nestle-Aland and many modern scholars to read, 'As in all the congregations of the saints, women should remain silent in the churches (Maier 2004).' Most traditional exegetes connect verse 33a with verse 33b. If Paul indeed 'condemned' women in 1 Corinthians 14:34-35 to silence in churches, he also barred them from all other forms of speaking in worship (Lenski 1963:615; Mare 1976:276). Another view is that the verses only forbid women from the use of certain gifts in church worship (Maier 2004).

\section{There are three imperatives in verses 34-35:}

- $\sigma \gamma \gamma \alpha \dot{\tau} \omega \sigma \alpha v$ [let them be silent] (v. 34)

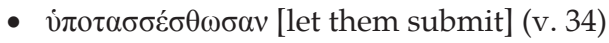

- $\dot{\varepsilon} \pi \varepsilon \rho \omega \tau \alpha ́ \tau \omega \sigma \alpha v$ [let them ask] (v. 35).
Only the two imperatives in verse 34 are significant to this

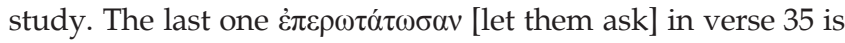
not significant because it focuses on domestic situation, and so is not thoroughly studied in this work.

$\Sigma \gamma \gamma \alpha \dot{\tau} \omega \sigma \alpha v$ [let them be silent] (v. 34) is verb imperative present

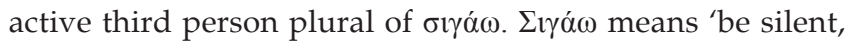
keep still, and say nothing' (Abbott-Smith 1922:405-4060. Arndt and Gingrich state that $\sigma \gamma \alpha \omega$ means 'say nothing' in Mark 14:61 and Acts 12:17; 'stop speaking' in 1 Corinthians 14:30 (cf. Luke 18:39; Acts 13:41); and 'conceal (something)' in Romans 16:25 (Arndt \& Gingrich 1957:757). The imperative

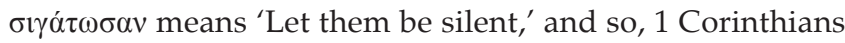

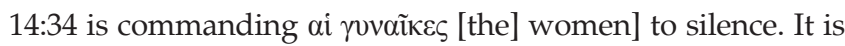

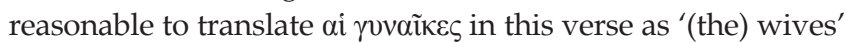

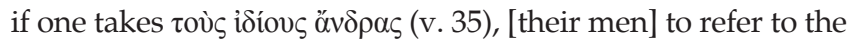
women's husbands. Arndt and Gingrich (1957:167) point out that the Greek word, yoví which means 'woman' as in Luke 13:11, means 'wife' in 1 Corinthians 9:5. The weakness of that interpretation is that it leaves out the single women and young

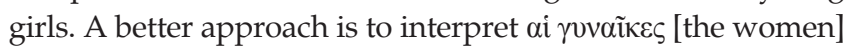
to refer comprehensively to all 'the women', and tov̀ sióous öv $\delta \rho \varsigma_{\varsigma}$ ['their men'] to refer to the women's husbands, fathers, brothers, or even uncles, as the case may be, living in the same house. This will generalise the command.

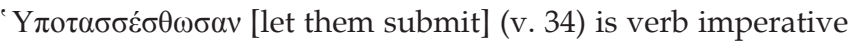
present passive third person plural from $\dot{\pi} \pi \tau \alpha \sigma \sigma \omega \omega^{\circ} \mathrm{Y} \pi \mathrm{o} \tau \sigma \sigma \sigma \omega$ means 'subject, bring under firm control, or subordinate'. Its active form is used in 1 Corinthians 15:27. Its middle form means 'to submit one's self' (Moulton 1977:419), but the form in 1 Corinthians 14:34 is passive and it means, 'they are to

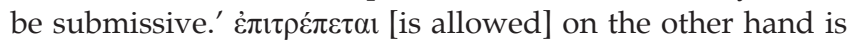
verb indicative present passive third person singular from $\dot{\varepsilon} \pi \imath \rho \varepsilon \dot{\pi} \pi \omega$ [I allow, I permit]. It means, 'to leave to the entire trust or management of someone,' hence 'to permit' (Moulton 1977:162). $\Lambda \alpha \lambda \varepsilon i v$ [to speak] is verb infinitive present active of $\lambda \alpha \lambda \varepsilon \omega \quad$ [I speak, I talk]. It means 'to talk, speak, or say' (Abbott-Smith 1922:263). But the question of who disallows women from 'speaking' is not addressed in the text. The combination of $\sigma \gamma \gamma \alpha \dot{\tau} \omega \sigma \alpha v$ [be silent] and, ov̉ ... $\lambda \alpha \lambda \varepsilon \tilde{\varepsilon} v$ [not ... to speak] in 1 Corinthians 14:34 forbids women to absolute silence in the church even from prophesying and praying in worship (Carson n.d.). There is a weaker word jंбuía, which primarily means 'quiet' in the sense of tranquil, used in 1 Timothy 2:11-12. However that term is not used in verse 34, rather $\sigma \gamma \gamma \alpha \omega$ [silence] is used. The verse therefore implies that women were to be absolutely silent during church services just as speakers in tongues were to be completely silent

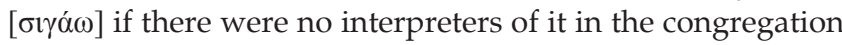
(1 Cor 14:28), and as prophets were to be silent [ $\sigma \gamma \gamma \alpha \omega \omega]$ under certain conditions (1 Cor 14:30) (Atkerson n.d.).

Robertson and Plummer (1961) represent another interpretation to 1 Corinthians 14:34 which allows women to join in saying 'amen' (cf. v. 16), and in prophesying in the church (pp. 324325). The contention is that if the text had intended to ban

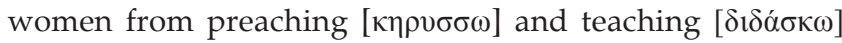
in the church it could have used the exact words for such 
activities since precise words exist. It is absurd to command women to absolute silence on the one hand and then permit them to prophesy in the church in the same Letter (Fee 1987:706-707) .The third interpretation has various forms. The main forms are considered below. The basis of the

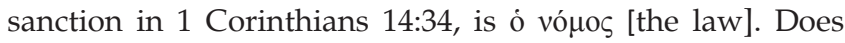
'the law' here refer to the Old Testament, the oral tradition later codified as the Talmud, the local command of the maledominated church in Corinth, or the demand of the Roman culture of that time? The reference is not likely to the Old Testament because there is no indication that Yahweh ever wanted women to be silent in worship. Rather the Psalmist calls on all the redeemed 'to confess' and 'praise the Lord' (Ps 107:2). Alana $(1992: 89,92)$ is of the opinion that the claim of 1 Corinthians 14:34-35 is contrary to the teaching in the Old Testament. Anyway if Paul had wanted to backup this sanction with the Old Testament like, for example in 1 Corinthians 9:8, he would have clearly cited the text.

If on the other hand the sanction was a liability from Judaism and Paul did support it, then he was a 'confused' man (House 1979:42-45). It is alleged that in Judaism, women were not allowed to ask questions, read from the Law, and contribute to discussions in Synagogues. Preato (n.d.) quotes Schleusner with approval that the reference here is to the Oral Law of the Jews. Preato explains that the Jewish prohibition of women to silence in worship is only found in the Talmud but the sanction could not have come from the Talmud either because it was a very late writing: its first part, Mishnah was written around 200 CE, whilst its second component, Gemara was written around $500 \mathrm{CE}$. A few others have even alleged that the sanction here betrayed an influence on Paul from Hellenism (cf. Alana 1992:89, 93). Payne (2009:37-40) concurs that the influence could be Roman, Hellenistic or Jewish. The problem with this line of interpretation is that it camps Paul against himself for he had earlier allowed women in the Letter to prophesy and pray (1 Cor 11:2-16; cf. Alana 1992:91), and had said that believers have been liberated from the law (Rm 3:28; 6:14; 7:16; Gl. 3:11-13; 4:5).

If 'the command' forbidding women from publicly talking could be a local law made by the Church in Corinth, and conveyed in another letter to Paul which he in turn quoted in 1 Corinthians 14:34-35 for the purpose of demolishing in verse 36 , then the idea is that verses $34-35$ do not represent Paul's verdict but others'.

This last interpretation presumes a local problem to escape conflict with 1 Corinthians 11:2-16 and the problem of the generic use of the term 'women' in 1 Corinthians 14:33-36 (Talbert 2002: 115-117). This interpretation also begs the question if some women were noisy, why were all women prohibited from talking? Were there no noisy men? If some women were uneducated and unruly, why were all women prohibited from talking? Were there no uneducated men? According to 1 Corinthians 14:33 the Corinthian church was not conforming to the church universal standard that appears to exceed the local. Examining the view that the Church in Corinth formulated its own law forbidding women from 'speaking' in worship services contradicts the fact that God has always used women in history as instruments of his revelation through preaching, teaching, praying, and counselling, to achieve 'his' goals, and that God is sovereign in the choice of the instruments he uses. This article re-affirms that God is sovereign in the choice of the ministers 'he' calls into church service and they are gifted for such work irrespective of their gender.

\section{Public ministry of women in Christ Apostolic Church}

The Christ Apostolic Church is a Pentecostal denomination. In fact, by her request for a Baptism in the Holy Spirit with visible signs following and distinct from salvation from sin, the church lays claim to being of a classical Pentecostal denomination. So women function prominently in the Christ Apostolic Church as in other Pentecostal denominations.

Some years ago, Pentecostals were not regarded as theologically and biblically sound but such accusations are dubious today. Theology of Pentecostalism is still being perfected. Experience does play a vital part in Pentecostal theology truth be told, but Scripture is equally important in the formulation of its theology.

Four things are vital in Pentecostal philosophy of women ministry (Benvenuti 1997; Barfoot \& Sheppard 1980:4) and these things are also important to women ministry in the Christ Apostolic Church. The first is the sense of a calling. Divine calling to serve is the first step in ministerial service in Christ Apostolic Church. This calling to the ministry which allegedly comes from God is to the individual and is expected to precede ministerial training. Margret Bola Odeleke and Dorcas Siyanbola Olaniyi illustrate this. Margret Bola Odeleke who later pulled out of the Christ Apostolic Church to found Power Pentecostal Church claimed to receive a divine calling in 1974 (History of Bishop Bolanle Odeleke n.d.) whilst Dorcas Siyanbola Olaniyi who also left the Christ Apostolic Church to start Agbala Daniel Church claimed to receive divine call into the ministry in 1979 (Adewale 1998:26). Odeleke and Olaniyi split from the Christ Apostolic Church to establish their separate denominations at the time the Christ Apostolic Church was undergoing an unparalleled crisis in its history and have since successfully piloted their churches (Fatokun 2006:7). Akintunde most likely misinterpreted the cause of the split of these women from the Christ Apostolic Church to be the failure of the denomination to ordain them because some other assemblies and ministries led by men also split and left the denomination around the same time, whilst some others led by men and women remained with the denomination (Akintunde 2001:98). This is not the forum to investigate that issue. But one person that began her ministry and concluded it within the Christ Apostolic Church was Joanah Omolola Ogunranti (1924-2007). She planted the first Christ Apostolic Church Bethel in the University of Ibadan in 1966. The Pentecostal Wednesday Prayer Meeting she started in Abadina in the University of Ibadan in 1969 led to the formation of the Christ Apostolic Church Students Association in 1970 in the same campus (Imevbore 2008). 
Another factor treasured by the Pentecostal churches is one's 'spiritual gift'. There are in the church Iya Aladura [Woman gifted in prayer], Iya Woli [Woman gifted in prophesying], Iya Onisoji [Woman gifted in conducting revival], and Iya Alasotele [Woman gifted in speaking in tongues]. The various women function within the Christ Apostolic Church in their areas of calling. Where a particular woman is the founder of the Christ Apostolic Church assembly, she freely uses all her spiritual gifts in the church. The Christ Apostolic Church recognises male and female revivalists who preach and exhort in their programs which may sometimes continue into Sunday worship services. The revivalists preach unhindered, irrespective of their gender, in such programs. The church cites Proverbs 18:16 to support this position, 'A man's gift makes room for him.' The word for 'man' in this Proverbs 18:16 is, אדם It is used in the context for the generic man, the human being. The commonest interpretation of this text in the Christ Apostolic Church is that a person's spiritual gifts determine her or his place of service in worship.

The third factor is the need of the world that is waiting for the salvation message of Christ. The urgency in the eschatology of Pentecostalism motivates them to evangelise. At the beginning of the Christ Apostolic Church, women were fully involved as Evangelists and Church Planters. Today, many women in Christ Apostolic Church are still on mission fields performing various ministerial roles beside the administration of baptism, marriage, and the Holy Communion.

Finally, the Pentecostals are thankful for the fulfillment of Joel's prophecy (J1 2:28-29). God has now poured out his Spirit on 'the sons and daughters' and they are now prophesying. The Christ Apostolic Church holds, as other Pentecostals do, that their women have no other option but to actively participate in the last days' work of the church since God has put his word in their mouths too.

There was a time when one Mrs O.O.A. Pearce was the Principal of the Christ Apostolic Church Bible College (19561973). She headed the school when it was still in Erio Ekiti (1956), Efon Alaye (1957-1967), and Akure (1968-1973). She was the only female head of the school, and she headed it the longest (Ogundeji 2012). She was removed in 1973 because she was a woman. But the fact that she got to that position in a male-dominated African society, in a school training only men, and for so long was a great achievement.

In recent times however the Christ Apostolic Church Seminary Ile-Ife and its campuses have reviewed their policies to accommodate women. For example, two women are now teaching in the Christ Apostolic Church Theological Seminary (CACTS) Main Campus, Opa, Ile-Ife, and most of the students they are teaching are men! Table 1 reflects how the Main Campus is working out this new policy. The study has not indicated how many men in comparison have qualified from the Theological Seminaries. It also seems that more women complete the certificate than the diploma. What are the comparisons to men again? It is significant that women do qualify as teachers, but as pastors?
TABLE 1: Gender of the seminary Main Campus's graduates.

\begin{tabular}{|c|c|c|c|c|c|c|c|}
\hline \multirow[t]{3}{*}{ Year } & \multicolumn{6}{|c|}{ Program } & \multirow[t]{3}{*}{ Total } \\
\hline & \multicolumn{2}{|c|}{ Certificate } & \multicolumn{2}{|c|}{ Diploma } & \multicolumn{2}{|c|}{ Degree } & \\
\hline & Women & Men & Women & Men & Women & Men & \\
\hline 2009 & 07 & 53 & - & 142 & - & - & 202 \\
\hline 2010 & 08 & 62 & 03 & 85 & - & - & 158 \\
\hline 2011 & 06 & 65 & 03 & 72 & 01 & 13 & 160 \\
\hline Total & 21 & 180 & 06 & 299 & 01 & 13 & 520 \\
\hline
\end{tabular}

Note: Data were collected directly from the various campuses by the Provost of the main seminary campus, Pastor Stephen O. Afolabi. The campuses are under the Main Seminary in Ile-Ife, Nigeria.

TABLE 2: Gender of the seminary Kabba's Campus graduates.

\begin{tabular}{lcccccc}
\hline Year & \multicolumn{4}{c}{ Program } & Total \\
\cline { 2 - 3 } \cline { 2 - 3 } \cline { 5 - 6 } & \multicolumn{2}{c}{ Certificate } & & \multicolumn{2}{c}{ Diploma } \\
\cline { 2 - 3 } & Women & Men & & Women & Men & \\
\hline 2009 & 03 & 16 & & 04 & 09 & 32 \\
2010 & 05 & 11 & & 04 & 28 & 48 \\
2011 & 06 & 10 & & 01 & 33 & 50 \\
\hline Total & $\mathbf{1 4}$ & $\mathbf{3 7}$ & & $\mathbf{0 9}$ & $\mathbf{7 0}$ & $\mathbf{1 3 0}$
\end{tabular}

Note: Data were collected directly from the various campuses by the Provost of the main seminary campus, Pastor Stephen O. Afolabi. The campuses are under the Main Seminary in lle-lfe, Nigeria.

Table 1 shows that the CACTS, Main Campus, Ile-Ife has turned out 28 females as compared with 492 male graduates from 2009 to 2011 in various categories. The school runs a two-year Certificate of Theology, a three-year Diploma in Theology, and a four-year Bachelor of Theology program. In 2009 the Main Campus, purely through its weekend program graduated 7 women with Certificate of Theology (Cert. Th.), whereas 53 men graduated with the same certificate, from the same program, in the same year. In addition, whereas no woman graduated that year with Diploma in Theology (Dip. Th.), 142 men graduated with the diploma. In 2010, whereas the Main Campus graduated 8 women with Cert. Th. and 3 with Dip. Th., it graduated 62 men with Cert. Th., and 85 with Dip. Th. In 2011, the Main Campus graduated 6 women with Cert. Th., 3 with Dip. Th., and 1 with Bachelor of Theology (B. Th.). These are in contrast with the 65 men that graduated with Cert. Th., 72 with Dip. Th., and the 13 with B. Th. in 2011.

Other CAC Theological Seminary campuses have turned out women graduates from 2009 to 2011.

Table 2 shows that the CACTS Kabba Campus did graduate 130 people from 2009 to 2011. The school runs a two-year Cert. Th. and a three-year Dip. Th. programs. In 2009 the school graduated 3 women as against 16 men with Cert. Th., and 4 women as against 9 men with Dip. Th. In 2010 the Campus graduated 5 women as against 11 men with Cert. Th., and 4 women as against 28 men with Dip. Th. In 2011 the school graduated 6 women as against 10 men with Cert. Th., and 1 woman as against 33 men with Dip. Th. That means that in the three years the school graduated 23 women and 107 men.

Table 3 shows that 194 people graduated from the CACTS Abuja Campus from 2009 to 2011. The school runs a two-year Cert. Th. and a three-year Dip. Th. programs. In 2009, the Campus graduated 4 women as against 16 men with Cert. Th., and 3 women as against 29 men with Dip. Th. In 2010 
TABLE 3: Gender of the seminary Abuja Campus graduates.

\begin{tabular}{lcccccc}
\hline Year & \multicolumn{4}{c}{ Program } & \multirow{2}{*}{ Total } \\
\cline { 2 - 3 } \cline { 2 - 3 } & \multicolumn{2}{c}{ Certificate } & & \multicolumn{2}{c}{ Diploma } \\
\cline { 2 - 3 } & Women & Men & & Women & Men & \\
\hline 2009 & 04 & 16 & & 03 & 29 & 52 \\
2010 & 05 & 10 & & 09 & 47 & 71 \\
\hline Total & 10 & 29 & & 05 & 27 & 71 \\
\hline
\end{tabular}

Note: Data were collected directly from the various campuses by the Provost of the main seminary campus, Pastor Stephen O. Afolabi. The campuses are under the Main Seminar in lle-lfe, Nigeria.

TABLE 4: Gender of the seminary Enugu Campus graduates.

\begin{tabular}{|c|c|c|c|c|c|}
\hline \multirow[t]{3}{*}{ Year } & \multicolumn{4}{|c|}{ Program } & \multirow[t]{3}{*}{ Total } \\
\hline & \multicolumn{2}{|c|}{ Certificate } & \multicolumn{2}{|c|}{ Diploma } & \\
\hline & Women & Men & Women & Men & \\
\hline 2009 & 13 & 17 & - & - & 30 \\
\hline 2010 & 06 & 14 & - & - & 20 \\
\hline 2011 & 06 & 18 & - & - & 24 \\
\hline Total & 25 & 49 & - & - & 74 \\
\hline
\end{tabular}

Note: Data were collected directly from the various campuses by the Provost of the main seminary campus, Pastor Stephen O. Afolabi. The campuses are under the Main Seminary in lle-Ife, Nigeria.

TABLE 5: Gender of the CAC Theological Seminary, Lagos Campus graduates.

\begin{tabular}{|c|c|c|c|c|c|}
\hline \multirow[t]{3}{*}{ Year } & \multicolumn{4}{|c|}{ Program } & \multirow[t]{3}{*}{ Tota } \\
\hline & \multicolumn{2}{|c|}{ Certificate } & \multicolumn{2}{|c|}{ Diploma } & \\
\hline & Women & Men & Women & Men & \\
\hline 2009 & 39 & 82 & 20 & 144 & 287 \\
\hline 2010 & 38 & 141 & 20 & 55 & 254 \\
\hline 2011 & 39 & 129 & 20 & 125 & 312 \\
\hline Total & 115 & 352 & 62 & 324 & 853 \\
\hline
\end{tabular}

Note: Data were collected directly from the various campuses by the Provost of the main seminary campus, Pastor Stephen O. Afolabi. The campuses are under the Main Seminary in Ile-Ife, Nigeria.

TABLE 6: Gender of the seminary Ede women Campus graduates.

\begin{tabular}{|c|c|c|c|c|c|}
\hline \multirow[t]{3}{*}{ Year } & \multicolumn{4}{|c|}{ Program } & \multirow[t]{3}{*}{ Total } \\
\hline & \multicolumn{2}{|c|}{ Certificate } & \multicolumn{2}{|c|}{ Diploma } & \\
\hline & Women & Men & Women & Men & \\
\hline 2009 & 78 & - & - & - & 78 \\
\hline 2010 & 91 & - & - & - & 91 \\
\hline 2011 & 55 & - & 21 & - & 76 \\
\hline Total & 224 & - & 21 & - & 245 \\
\hline
\end{tabular}

Source: Kariola, E.O., 2012, 'The historical background of the CAC theological seminary, Ede women campus', a mimeograph report prepared by the Coordinator of the Campus for the Provost of the CAC Theological Seminary Main Campus, Opa, lle-Ife

the Campus graduated 5 women as against 10 men with Cert. Th., and 9 women as against 47 men with Dip. Th. In 2011 the school graduated 10 women as against 29 men with Cert. Th., and 5 women as against 27 men with Dip. Th. In all, 36 women and 158 men graduated from the Campus from 2009 to 2011.

The CACTS Enugu Campus represents the campus of the CACTS in the Eastern Zone. The school runs only a twoyear Cert. Th. program. As shown on Table 4, the school has graduated 74 people. In 2009 it graduated 13 women as against 17 men. In 2010, it graduated 6 women as against 14 men. In 2011, the school graduated 6 women as against 18 men. In all, CACTS Enugu Campus has graduated 25 women as against 49 men from 2009 to 2011.

The CACTS Enugu Campus represents the theological training embarked upon by the CAC in the Eastern Zone.
As shown on Table 4, the school graduates women only in the two-year Cert. Th. program. In three years, 2009-2011, it turned out 25 female graduates.

The CACTS Campuses in Lagos (Table 5) and Ede (Table 6) represent the training provided by the denomination in the Western Zone. Table 5 reveals that 853 people have graduated from CACTS Lagos Campus from 2009-2011. The Campus runs a two-year Cert. Th. and a three-year Dip. Th. programs. In 2009, the Campus graduated 39 women as against 82 men with Cert. Th., and 22 women and 144 men with Dip. Th. In 2010 the school graduated 38 women as against 141 men with Cert. Th., and 20 women as against 55 men with Dip. Th. In 2011 the Campus graduated 38 women as against 129 men with Cert. Th., and 20 women and 125 men with Dip. Th. In all, 177 women and 676 men graduated from the Lagos Campus from 2009 to 2011.

Table 6 shows that 245 people graduated from the CACTS Ede Campus from 2009 to 2011. As expected, all the graduates are women. The Campus runs a two-year Cert. Th. and a three-year Dip. Th. programs. In 2009, 78 women graduated with Cert. Th. In 2010, the Campus graduated 91 women with Cert. Th. The first set of Dip. Th. program candidates were admitted into the school in 2009, and they were not ready to graduate till 2011. So in 2011, the school graduated 55 women with Cert. Th., and 21 with Dip. Th. That means that the school graduated 245 women for ministry in three years. In all the Ede Campus has turned out 1217 graduates from 1986 to 2011 (Kariola 2012).

The Christ Apostolic Theological Seminary Women Campus Ede is in a class of its own. In 1975, E.O. Jojolola established the Women School of Prophetesses but the CAC Authorities only gave approval to its establishment in 1986. It was in 1986 that the school changed its name to CAC Women Bible College. In 1996, its name changed again to CAC Theological Seminary, Ede Women Campus. From 1976 to 2008, the school graduated 962 women with one-year general Bible Institute Certificate. In 2009 (Table 5), it graduated 78 women with two-year Cert. Th.; in 2010 it graduated 91 women with two-year Cert. Th.; and in 2011 it graduated 55 women with two-year Cert. Th. and 21 women with three-year Dip. Th. That means that the school graduated 245 women for ministry in three years. In all the Ede Campus has turned out 1217 graduates from 1986 to 2011 (Kariola 2012).

All the tables above show the importance attached to women preaching and teaching ministries in the CAC. The Seminary that teaches women up to Dip. Th. and more recently up to Bachelor of Theology degree level is not sending them out to be silent. It is sending them out to teach others and to proclaim the word of God.

It is important to note that this article leaves out the issue of women ordination in the CAC which is the focus of Akintunde's article (2001:98). She did not give attention to the overwhelming evidence in the CAC that show that women are actively 'talking' in the church's worship services. 


\section{A re-examination of 1 Corinthians $14: 34-36$ in the context of the Christ Apostolic Church}

Which interpretive option of 1 Corinthians 14:34-35 resonates with the Pentecostal hermeneutics which takes the Bible seriously and values pneumatic experience highly? The fact that God is still calling women to work in the church, that he is still equipping them for the work with spiritual gifts, that available hands for the world harvest are not enough, and that these are the last days when God is pouring out his prophetic gifts upon men and women requires a reinterpretation of 1 Corinthians 14:34-35 that do not limit women 'speaking' ministry in and outside the church. Again, because the Pentecostals are literalists, they hold even the letters of the Bible to be the word of God, except in the face of overwhelming proof of corruption which is not available here. The interpretation adopted here therefore takes 1 Corinthians 14:34-35 as a local sanction imposed on women on the Corinthians' church but re-stated and rejected by Paul in verse 36 . So verse 36 can be re-stated thus, 'What? Was it from you that the word of God went forth? Or did it come unto you alone?' A possible implication of this is that Paul here distanced himself from the law that forbade women to speak in the church because the law negated the principle of gender equality in Christ. So 'the law' referred to in verse 34 is to the one created by the Corinthians and not the one in the Old Testament.

A greater problem today is that many have universalised this sanction and many people are suffering from this. Where women are barred from publicly proclaiming the word of God, other members of the Christian community miss out on their contributions. Some women are gifted Bible preachers, expositors, counsellors, Evangelists and Prophetesses. There are times when the church has better gifted men around, but there are times when the women available are better suited for the jobs on the ground.

\section{Concluding remarks}

Elijah O. Babalola (1992:43) compares favourably the pastoral functions of women in indigenous Pentecostal churches like the Christ Apostolic Church with their roles in African Indigenous Religions where they serve as priestesses and wives of divinities. His observation is factual. Certainly, the last has not been heard on the talking role of women in the church of Christ. The effort to discern the correct meanings of various relevant texts on the topic is continuing. From the practical points of view, denying women the chance to contribute simply because they are female is sexist, self destructive, backward, and arrogant. The women would not experience fulfilment because they are hindered from maximally serving in the church. Other members would sometimes be denied the benefit of getting the best in spiritual contributions if they are entrusted to the hands of women. Mediocracy may be promoted on the altar of gender hatred, and the progress of the gospel would be retarded on reasons of hard-heartedness rather than theological expediency.

\section{Acknowledgements Competing interests}

The authors declare that they have no financial or personal relationship(s) which may have inappropriately influenced them in writing this paper.

\section{Authors' contributions}

G.O.F. (Obafemi Awolowo University, Ile-Ife, Nigeria) was the research leader. He designed the work and and interpreted the biblical text from the CAC women context. S.O.A. (Christ Apostolic Church Theological Seminary, IleIfe, Nigeria) collected data of graduates from the Seminary's main campus in Ile-Ife and five of its campuses.

\section{References}

Abbott-Smith, G., 1922, A manual Greek lexicon of the New Testament, T \& T Clark, Edinburgh.

Adewale, S.A., 1998, Women in religion: A socio-religious analysis of the roles and position of women in religions, Sudan Commercial Press, Lagos.

Ademilokun, M.K., 1998, 'Discriminatory policy and women: An overview of Yoruba traditional religion', in G. Aderibigbe \& D. Ayegboyin (eds.), Religion and family, pp. 57-60, Nigerian Association for the Study of Religions and Education.

Akintunde, D.O., 2001, 'No longer be silent: A critique of women's silence in Christ Apostolic Church, Nigeria', in D.O. Akintunde (ed.), African culture and the quest for women's rights, pp. 85-102, Sefer, Ibadan.

Alana, E.O., 1992, 'Paul's theology of liberation of womanhood - Fetters of conservationism with particular reference to women leadership in the Cherubim and Seraphim Church', African Journal of Biblical Studies 7(1), 89-97.

Arndt, W.F. \& Gingrich, F.W., 1957, A Greek-English lexicon of the New Testament and other early Christian literature, University of Chicago Press, London.

Atkerson, S., n.d., 'Correctly interpreting 1 Corinthians 14:33b-35 (Part 1)', in Reforming today's church with New Testament practices, viewed 01 March 2012, from http://www.ntrf.org/articles/article_detail.php?PRKey=16

Babalola, E.O., 1992, 'Women in Aladura churches: A biblio-theological study of women in Aladura pastoral ministry in Yoruba Land', African Journal of Biblical Studies 7(1), 40-47.

Barfoot, C.H. \& Sheppard, G.T., 1980, 'Prophetic vs. priestly religion: The changing role of women clergy in classical Pentecostal churches', Review of Religious Research 22(1), 2-17. http://dx.doi.org/10.2307/3510481

Barrett, C.K., 1968, Black's New Testament commentary: A commentary on the first epistle to the Corinthians, 2nd edn., Adak and Charles Black, London.

Benvenuti, S.R., 1997, 'Pentecostal women in ministry: Where do we go from here?', viewed 18 March 2012, from http://www.pctii.org/cyberj/cyberj1/ben.html

Carson, D.A., n.d., 'Silent in the churches: the role of women in 1 Corinthians 14: 33b36', viewed 04 March 2012, from http://bible.org/seriespage/silent-churchesrole-women-1-corinthians-1433b-36

Conzelmann, H., 1975, 1 Corinthians: A commentary on the first epistle to the Corinthians, Fortress, Philadelphia.

Derstine, Todd, n.d., 'Should women be silent in the church? 1 Corinthians 14:334-35', viewed 01 March 2012 from http://www.todd-derstine. com/americaspropheticdestiny/should-women-be-silent-in-church-icorinthians-1434-35/

Fatokun, S., 2006, 'Women and leadership in Nigerian Pentecostal churches', Studia Historiae Ecclesiasticae 32(3), 193-205.

Fee, G., 1987, The first epistle to the Corinthians, Eerdmans, Grand Rapids.

Gilmour, S.M., 1962, 'First letter to the Corinthians', in G.A. Buttrick, T.S. Kepler, J. Knox, H.G. May, S. Terrien, \& E.S. Bruke et al. (eds.), The interpreter's dictionary of the Bible, vol. 1, pp. 684-692, Abingdon, Nashville.

Hafemann, S.J., 1993, 'Letters to the Corinthians', in G.F. Hawthorne, R.P. Martin \& D.G. Reid (eds.), Dictionary of Paul and his letters, pp. 164-179, InterVarsity, Leicester.

History of Bishop Bolanle Odeleke, viewed on 18 March 2012 from http://www. bishopbolanleodeleke.org/

House, H.W., 1979, 'Paul, women, and contemporary Evangelical feminism', Bibliotheca Sacra 136(451), 40-53.

Imevbore, A.M.A., 2008, 'History of Joanah Omolola Ogunranti', in Joanah Omolola Ogunranti Foundation, viewed 04 March 2012, from http://www.oluwoleogunranti. $\mathrm{com} /$ foundation/joofoundation.htm

Kariola, E.O., 2012, 'The historical background of the CAC theological seminary, Ede women campus', a mimeograph report prepared by the Coordinator of the Campus for the Provost of the CAC Theological Seminary Main Campus, Opa, Ile-Ife. 
Keener, C.S., 1993a, The IVP Bible background commentary: New Testament, InterVarsity, Downers Grove.

Keener, C.S., 1993b, 'Man and woman', in G.F. Hawthorne, R.P. Martin \& D.G. Reid (eds.), Dictionary of Paul and his letters, pp. 583-592, InterVarsity, Leicester.

Keener, C., 2005, 'Learning in the assemblies: 1 Corinthians 14:34-35', in R.W. Pierce, R. Merrill Groothuis, \& G.D. Fee (eds.), Discovering biblical equality: Complementarity without hierarchy, 2nd edn., pp. 161-171, InterVarsity, Downers Grove.

Lenski, R.C., 1963, The interpretation of St. Paul's first and second epistles to the Corinthians, Augsburg, Minneapolis.

Maier, W.A., 2004, 'An exegetical study of 1 Corinthians 14:33b-38', viewed 01 March 2012, from http://www.mtio.com/articles/bissar47.htm

Mare, W.H., 1976, '1 Corinthians', in F.E. Gaebelein, W.C. Kaiser, B.K. Waltke, J.M. Boice, M.C. Tenney, \& G.H. Terpstra (eds.), The expositor's Bible commentary, vol. 10, pp. 173-298, Zondervan, Grand Rapids.

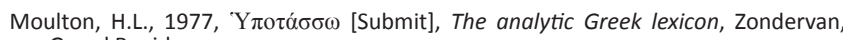
Grand Rapids.

Morris, L., 1979, The first epistle of Paul to the Corinthians, Eerdmans, Grand Rapids.

Murphy-O'connor, J., 1990, 'The first letter to the Corinthians', in R.E. Brown, J.A. Fitzmyer \& R.E. Murphy (eds.), The Jerome biblical commentary, pp. 798-815, St. Paul, Ibadan.

Nelson, D.P., 2005, 'Learning in the assemblies: 1 Corinthians 14:34-35', Journal for Biblical Manhood and Womanhood 10(1), 22-28.
Okunola, O.A., 2001, 'Menstrual blood and priestly roles', in D.O. Akintunde (ed.) African Culture and the Quest for Women's Rights, pp. 25-34, Sefer, Ibadan.

Ogundeji, M.A., 2012, 'Christ Apostolic Church theological seminary alumni association', a mimeograph paper presented by the Chairman of the CAC theological seminary alumni association to the annual conference CAC Theological Seminary Main Campus, Ile-Ife, Nigeria, 14 March.

Payne, P.B., 2009, Man and woman, one in Christ, Zondervan, Grand Rapids.

Payne, P.B., 1995, 'Fuldensis, Sigla for Variants in Vaticanus, and 1 Cor 14. 34-5', in New Testament Studies 40, 240-262.

Payne, P.B., 2010, 'Responses to Questions about 1 Cor. 14:34-35 as an Interpolation', viewed 03 March 2012, from http://www.box.com/shared/uffvq3df29 http:// dx.doi.org/10.1017/S0028688500021263

Preato, D.J., n.d., 'Did Paul really say, "Let the women keep silent in the churches?" in God's word to women, viewed 01 March 2012, from http://godswordtowomen. org/Preato2.htm

Robertson, A. \& Plummer, A., 1961, The international critical commentary: A critical and exegetical commentary on the first epistle of St. Paul to the Corinthians, 2nd edn, T \& T Clark, Edinburgh.

Talbert, C.A., 2002, Reading Corinthians: A literary and theological commentary, rev. edn., Smyth \& Helwys, Macon, GA.

Wallace, D.B., 1998, 'The textual problem of 1 Corinthians 14:34-35', viewed 01 March 2012, from http://bible.org/article/textual-problem-1-corinthians-143435\#P11_1048 